\title{
Dehydration, Nutrient Analysis, Phytochemical Analysis and Shelf Life Assay of Citrus Fruit Peel
}

\author{
Raajeswari PA* and Nischala \\ Department of Food Science and Nutrition, Avinashilingam Institute for Home Science and Higher Education for Women, India
}

Submission: November 01, 2017 Published: December 11, 2017

*Corresponding author: Raajeswari PA, Department of Food Science and Nutrition, Avinashilingam Institute for Home Science and Higher Education for Women, India, Email: raajraajeswari@gmail.com

Abstract

Citrus is a common fruit which contains multiple beneficial nutrients and active phytochemicals that can provide health that are mainly used in juice processing industries and often the peel is discarded as waste. The citrus peel which is a primary waste contains many phytochemicals, flavonoid glycosides, coumarins $\beta$, volatile oils and antioxidants. Citrus peels are rich in phenolic compounds that can protect health. It also provides an ample supply of vitamin C, folic acid, potassium and pectin. Citrus peel is rich in flavonoids that have anti-cancer, antiviral, and antiinflammatory activities. In the present study, citrus peel that is thrown of as food waste was dehydrated and used for analysis. The dried citrus fruit peel was analyzed for its nutrient content such as carbohydrates, protein, fat, fibre and calcium. Citrus peel was also tested for the presence of phytochemicals. Phytochemical screening showed the presence of flavonoids, phenols, glycosides and coumarins.

\section{Introduction}

Fruit peels are the protective coverings of the fruits which are generally considered as a waste material and are discarded after fruits consumption but many recent investigations have proved that these fruit peels may contain many bioactive constituents which have various significant medicinal and pharmacological properties [1]. Assini et al. [2] stated that the biochemical functions of flavonoids in orange peel have been studied extensively recently. They increased serum antioxidant capacity against lipid per oxidation and reduced the elderly oxidative stress. Terpstra studied the effectiveness of citrus peel in lowering the plasma liver cholesterol, serum triglyceride level, serum total cholesterol, liver total lipids and liver cholesterol.

Shimon M et al. [3] stated that the fibre of citrus fruit contains bioactive compounds, such as polyphenols, the most important being vitamin $\mathrm{C}$ and they certainly prevent and cure vitamin C deficiency which is the cause of scurvy. Many studies have reported that antioxidant and antibacterial effect of juice and edible parts of lemon and oranges of different varieties. As far as the peel is concerned, extracts from this part of the fruit were found to have a good total radical anti-oxidative potential.

Recent studies indicate that peel yields thousands fold more phenolic compound than pulp. Reviews suggest that flavonoids and phenolics were significantly greater in peel than the pulp, seeds and hence their fruit husk extracts shows antiproliferative activity against a panel of human oral, colon and prostate cancer cell lines. Citrus fruits were historically used for their high content of vitamin C; various studies elucidate their Radical Trapping Anti-oxidant Potential (TRAP) that was significantly higher in peels than in peeled fruits. Citrus fruit contain high concentration of phenols, flavonoids, glycosides, hesperidins, hydrixycinnamates and its flavones analogue, diosmin etc., that all have exhibited anti-carcinogenic activity in various in vitro studies [4].

\section{Methodology}

\section{Procurement of citrus fruits - raw materials}

Orange, Sweet lime and Lemon were selected from the citrus family. These citrus fruits were purchased from the local fruit shop in Coimbatore city. Some citrus Peel was collected from local fruit juice shops in Coimbatore city. Orange, Sweet lime and Lemon with bruises, signs of infection and those different from the group were discarded from the samples. Uniform, unblemished citrus fruits were selected and hand washed with tap water to remove soil particles and to reduce microbial population on the surface. Then the fruits were surface dried with soft cloth and peeled by hand and immersed in warm water for few minutes, several times and the water has been drained out to remove the bitterness of peel.

\section{Dehydration of citrus peel}

Drying is a process in which water is removed to halt or slow down the growth of spoilage microorganisms as well as the occurrence of chemical reactions. The terms dried 
and dehydrated are not synonymous. The US Department of Agriculture lists dehydrated food as those with not more than $2.5 \%$ water (dry basis) while dried food apply to any food product that has been exposed to a water removal process which has more than $2.5 \%$ water (dry basis). Drying is used in addition to preservation, to reduce the cost or difficulty of packaging, handling, storing and transporting by converting the raw food to a dry solid. This reduces the weight and volume.

Citrus peel is dehydrated using cabinet dryer also known as tray dryer. Tray dryer consist of an insulated cabinet fitted with shallow mesh or perforated trays, each of which contains a thin (2-6cm deep) layer of food. Fresh air enters the cabinet is drawn by the fan through the heater coils and is then blown across the food trays to exhaust. The air is exhausted to the atmosphere after one pass rather being re-circulated within the system evaporating water from food would have to be dried before being re-circulated. They commonly are used to dry fruit and vegetable pieces and depending upon the food and the desired final moisture, drying time may be of the order of 10 or even $20 \mathrm{hr}$. They are simplified design and relatively low operating costs and inexpensive alternative to the more costly belt type dryers and hence dehydration process is carried by cabinet dryer [5].

The peels of orange, sweet lime and lemon were cut into small pieces for quick and equal drying. Then they were immersed in warm water for several times and the water was poured out to remove the bitterness. The citrus peels were kept for dehydration in tray dryer at 60 oC for 12 hours. The crisp and brittleness of peel proved that they are completely dried and then used for powdering. The dried peels are collected and powdered using grinder and are sieved to get fine powder.

\section{Nutrient and Phytochemical Analysis of the Dehydrated Citrus Peel}

\section{Nutrient analysis}

Analysis of nutrient content is an important aspect in standardizing and developing a new product and evaluating a new process for making food products and identifying the sources of problem with unacceptable problem. Adequate analytical methods for nutrients in foods, food ingredients and food products are the basic first step in determining the nutritional adequacy of a food supply. Consumer education via food labels, database of nutrient and deficiency disease studies and the assay used to provide the data must determine the analysis of interest adequately [6].

Citrus peel powder was subjected to the analysis of proximate principles such as energy, carbohydrate, protein, fat, calcium and fibre.

i. Energy: Bomb calorimeter is based on the fact that a known weight of the sample completely burnt in the apparatus permits the heat developed by the combustion to be absorbed by a definite weight of water. By determining the rise in temperature, it is possible to calculate within close limits, the number of heat units liberated [7].

ii. Carbohydrate: Carbohydrates are hydrolyzed into sample sugar using dilute hydrochloric acid. In hot acidic medium glucose is dehydrated to hydroxyl methyl furfural. This compound forms with an throne, a green colour with an absorption maximum at $630 \mathrm{~nm}$ [7].

iii. Protein: The most widely used method for protein determination is by Kjeldhal method for nitrogen determination. Since nitrogen is the characteristic element in protein, by its accurate determination, protein concentration can be calculated. This method involves two steps. In the first step protein is digested using sulphuric acid in the presence of a catalyst. In this step II the organic material is oxidized except nitrogen, the reduced form of which is retained in digest as ammonium sulphate. Then ammonia is distilled and collected in boric acid and titrated against standard acid [8].

iv. Fat: Fat content of the sample was determined by soxhlet extraction method. The extraction of the crude fat is carried out using petroleum ether in a soxhelt unit followed by volatilization of solvent after extraction and determination of mass of the residue.

v. Calcium: Calcium is determined by precipitating it as calcium oxalate and titration of oxalate solution in dilute sulphuric acid against standard potassium permanganate [7].

vi. Fibre: Fibre estimation was done by acid, alkali boiling method. The values obtained were expressed as grams of fibre per $100 \mathrm{grams}$ of sample.

vii. Moisture: Moisture was assessed through Shimadzu moisture balance MOC-120H. The moisture balance consists of two fuses that create heat to the food sample plate and the moisture from the food sample is removed.

\section{Phytochemical analysis}

i. Preparation of extract: $10 \mathrm{~g}$ of the sample was taken and added $50 \mathrm{ml}$ of water. The solution was filtered with whatman filter paper No. 1 and centrifuged. The supernatant clear liquid was collected and used for further analysis.

ii. Tannins: About 0.5g of the dried sample was boiled in $20 \mathrm{ml}$ of water in a test tube and filtered. A few drops of $0.1 \%$ ferric chloride was added and observed for brownish green or a blue black colouration [9].

iii. Phenols: To $1 \mathrm{ml}$ of the extract, $2 \mathrm{ml}$ of distilled water followed by few drops of $10 \%$ ferric chloride was added. Formation of blue or green indicates presence of phenols [9]. 
iv. Flavonoids: To $2 \mathrm{ml}$ of plant extract, $1 \mathrm{ml}$ of $2 \mathrm{~N}$ sodium hydroxide was added. Development of yellow colour indicates the presence of Flavonoids [9].

v. Saponins (Foam test): $5 \mathrm{ml}$ sample extract dissolved in $2.5 \mathrm{ml}$ of dilute water and shaken vigorously till a stable persistent froth was obtained. The froth was mixed with 3 drops of olive oil and shaken vigorously and then emulsion was observed [9].

vi. Glycosides: To $2 \mathrm{ml}$ of the plant extract, $3 \mathrm{ml}$ of chloroform and 10\% ammonia solution was added. Formation of pink colour indicates presence of glycosides [9].

vii. Coumarins: To $1 \mathrm{ml}$ of the extract $1 \mathrm{ml}$ of $10 \% \mathrm{NaOH}$ was added. Formation of yellow colour indicates the presence of coumarins [9].

The physical, physicochemical and phytochemical test was done in triplicates to get concordant values.

\section{Shelf Life Test}

Microbial analysis was carried for the citrus peel powder. The powder was stored in zip lock covers. The microbial content of the sample was estimated for the first week and second week. Shelf life is the recommendation of time that products can be stored during which the defined quality of a specified proportion of the food remains acceptable under expected conditions of storage [10].

Shelf life is most influenced by several factors such as exposure to light and heat, transmission of gasses, humidity, mechanical stress and contamination by microorganism. Microbiological analysis is important to determine the safety and quality of food.

\section{Results and Discussion}

\section{Nutrient content of citrus peel powder}

The nutrient content of citrus peel dehydrated through cabinet drying was assessed [8]. The nutrient content of citrus peel powder is given in Table 1 .

Table 1: Nutrient content of citrus peel powder.

\begin{tabular}{|c|c|c|}
\hline S. NO & Nutrients & $\begin{array}{c}\text { Citrus Peel Powder } \\
\text { (per 100g) }\end{array}$ \\
\hline 1 & Energy (Kcal) & 82.22 \\
\hline 2 & Carbohydrates (gm) & 18.67 \\
\hline 3 & Protein (gm) & 1.66 \\
\hline 4 & Fat (gm) & 0.10 \\
\hline 5 & Calcium (mg) & 163.33 \\
\hline 6 & Fibre (mg) & 10 \\
\hline 7 & Moisture & $9.70 \%$ \\
\hline
\end{tabular}

From the Table 1 it is obvious that citrus peel powder contains $163.33 \mathrm{mg}$ of calcium, $10 \mathrm{mg}$ of fibre, $1.66 \mathrm{~g}$ of protein, $18.67 \mathrm{~g}$ of carbohydrates and $82.22 \mathrm{kcal}$ of energy. Citrus peel powder is rich in calcium and fibre but it is low in fat. It consists of $0.10 \mathrm{~g}$ of fat in $100 \mathrm{~g}$ of citrus peel powder. The moisture content was found to be 9.7 per cent in citrus peel powder.

The results of the present study are related to USDA [11] where the quantity of nutrient content per $100 \mathrm{~g}$ was given and the nutrients like fibre, fat, protein and calcium were similar to the results of the present study.

\section{Phytochemical analysis of citrus peel powder}

Qualitative screening of citrus peel powder was carried out to screen for the presence of various phytochemicals namely tannins, phenols, flavonoids, saponins, steroids, glycosides and coumarins [9]. The results of phytochemical screening are shown in Table 2.

Table 2: Phytochemical analysis of citrus peel powder.

\begin{tabular}{|c|c|c|c|}
\hline S. NO & Phytochemicals & $\begin{array}{c}\text { Aqueous } \\
\text { Extract }\end{array}$ & Inference \\
\hline 1 & Tannins & - & $\begin{array}{c}\text { Presence of Blue black } \\
\text { colour }\end{array}$ \\
\hline 2 & Phenols & + & Presence of Green colour \\
\hline 3 & Flavonoids & ++ & Presence of Yellow colour \\
\hline 4 & Saponins & - & Absence of froth formation \\
\hline 5 & Glycosides & + & Presence of Pink colour \\
\hline 6 & Coumarins & + & Presence of Yellow \\
\hline
\end{tabular}

The phytochemical screening was done with aqueous extract as aqueous extract will contain the whole compound of source material. Raja Nagappan [12] reported in a study that aqueous extract was far better than ethanol extract and was high in concentration. The phytochemical screening of the aqueous peel extracts confirmed the presence of tannin, phenols, glycosides, steroids, flavonoids and coumarins. The flavonoid content in the peel was seen to be highly positive. Phenols, steroids, glycosides and coumarin had shown positive. The peels did not show the presence of saponins.

Similar results were reported in a study done by Blessy et al. [13]. Where, the presence of phenols, flavonoids, tannins and glycosides was confirmed in citrus peel. Arora et al. [14] also confirmed the presence of tannins in orange peel.

\section{Shelf life study of citrus peel powder}

Microbial analysis of the powder presented in Table 3.

Table 3: Microbial Analysis of Citrus peel powder.

\begin{tabular}{|c|c|c|c|}
\hline S.No & Sample & $\begin{array}{c}\text { Microbial } \\
\text { Plate Count } \\
\text { (cfu/ml) }\end{array}$ & \\
\hline & & Week I & Week II \\
\hline 1 & $\begin{array}{c}\text { Citrus Peel } \\
\text { Powder }\end{array}$ & $1 * 105$ & $2 * 105$ \\
\hline
\end{tabular}


$50 \mathrm{gm}$ of citrus peel powder was packed in zip lock cover for two weeks and kept under room temperature. The sample was evaluated for the microbial plate count (cfu/ml) by spread plate method. The sample had no bacterial growth in the first week and very few colonies in the second week which is considered to be as less count. The sample was found to be acceptable during both the first and second week. The citrus peel powder was found to be acceptable while storing in the zip lock cover it showed low microbial plate count.

\section{References}

1. Kim H, Moon JY, Kim H, Lee DS, Cho M, et al. (2010) Antioxidant and antiproliferative activities of mango (Magnifera indica L.) flesh and peel. Food Chem 121: 429-436.

2. Assini JM, Mulvihill EE, Sutherland BG, Telford DE, Sawyez CG (2013) Naringenin prevents cholesterol-induced systemic inflammation, metabolic dysregulation nd atherosclerosis in Ldlr/mice JLip Res 54(3): 711-724.

3. Shimon M, Joseph K, Bezalel A, Sonia PH (2012) J Agric Food Chem 60 : 1813.

4. Li R (2006) Citrus peel extract shown to reduce insulin resistance may help diabetics. Natural News 79: 365-373.
5. Geankoplis CJ (2003) Transport Processes and Unit Operations, $3^{\text {rd }}$ (Edn), Prentice-Hall International, Inc., New Jersey, USA.

6. Jonathan W, De Vries, (2006) AOAC International Validation Methods for Nutrient Analysis Method Availability and Method Needs 50: 53.

7. AOAC (2004) AOAC official method Pp. 935.

8. FSSAI (2012) Manual method of analysis of foods Pp 57

9. AOAC (2005) AOAC official method.

10. Akbar S (2008) Processed food industry Pp. 46

11. USDA (2016) National Nutrient Database for Standard Reference.

12. Raja N (2012) Evaluation of aqueous and ethanol extract of bioactive medicinal plant, Cassia didymobotrya (Fresenius) Irwin \& Barneby against immature stages of filarial vector, Culex quinquefasciatus Say (Diptera: Culicidae), Asian Pac J Trop Biomed Sep 2(9): 707-711

13. Blessy BM, Suresh KJ, Archana T (2012) Phytochemical analysis of citrus limonum pulp and peel. International Journal of Pharmacy and Pharmaceutical Sciences 4(2): 269-371

14. Arora M, Parminder K (2013) Phytochemical screening of orange peel and pulp. IJRET: International Journal of Research in Engineering and Technology, 2(12): 517-520.

\section{Your next submission with Juniper Publishers} will reach you the below assets

- Quality Editorial service

- Swift Peer Review

- Reprints availability

- E-prints Service

- Manuscript Podcast for convenient understanding

- Global attainment for your research

- Manuscript accessibility in different formats ( Pdf, E-pub, Full Text, Audio)

- Unceasing customer service

Track the below URL for one-step submission https://juniperpublishers.com/online-submission.php 